\title{
Assessment of tree species diversity, composition and structure of Medha Kachhapia National Park, Cox's Bazar, Bangladesh
}

\author{
MEHRAJ UDDIN, FAQRUL ISLAM CHOWDHURY", MOHAMMED KAMAL HOSSAIN \\ Institute of Forestry and Environmental Sciences, University of Chittagong. Chattogram-4331, Bangladesh. `email: faqrul@cu.ac.bd
}

Manuscript received: 17 January 2020. Revision accepted: 2 May 2019.

\begin{abstract}
Uddin M, Chowdhury FI, Hossain MK. 2020. Assessment of tree species diversity, composition and structure of Medha Kachhapia National Park, Cox's Bazar, Bangladesh. Asian J For 4: 15-21. Tree species diversity assessment is considered an essential task to design robust conservation action plans of Protected Areas (PAs). Numerous researches have assessed tree diversity of different PAs of Bangladesh but tree diversity of Medha Kachhapia National Park (MKNP) is still unknown due to lack of research initiatives. It hinders forest managers of this PA to plan and implement conservation actions successfully. To this end, the study carried out a systematic sampling to ascertain composition, distribution, and diversity of tree species in MKNP. Findings revealed that representation of tree diversity of MKNP was very poor. Only 10 tree species representing 6 families were identified. Besides, MKNP was dominated by different Dipterocarpus spp. especially by Dipterocarpus costatus. Dominance in height and diameter classes and high Important Value Index (133.94) of D. costatus indicated that the tree might find a suitable habitat in MKNP to maintain optimum dispersal, development, and growth. However, recent plantation activities with exotic Acacia auriculiformis and intensified human-induced disturbances might hamper its habitat. Thus, to conserve the habitat of D. costatus and remaining forest resources of MKNP, reforestation efforts should be shifted from exotic to native tree species, and community anthropogenic disturbances should be minimized.
\end{abstract}

Keywords: Dipterocarpus costatus, exotic vs. natural, importance value index, tree diversity, protected area

\section{INTRODUCTION}

Bangladesh has $17.47 \%$ forest areas compared to the total land surfaces of the country (BFD 2019). However, the actual forest cover does not exceed $6 \%$ of the country's total land, and forest land per capita is only about 0.022 ha (FMP 1993). This small tract of forest land is not sufficient to maintain the ecological balance to provide continuous flows of ecosystem goods and services for the everincreasing people in the surrounding forests of Bangladesh. Moreover, such a small tract of forest land is also under threats of illegal felling, forest encroachment, and intensification of land-use changes. The increasing trend of forest deforestation and intensification of anthropogenic activities inside the forest areas causes a serious erosion of genetic resources from the terrestrial ecosystems of Bangladesh (Hossain 2001; Rahman and Hossain 2002; Motaleb and Hossain 2011). Such erosion of biodiversity from the forest lands creates negative impacts on the ecosystem functioning (Liang et al. 2016).

Forests of Bangladesh were once rich with more than 5,000 species of angiosperms and 1,609 species of fauna (IUCN 2000; Hossain 2001; Ahmed et al. 2008; Sobuj and Rahman, 2011). However, for some species, half of the population has declined during the last decades, and about $13 \%$ of vascular plant species become threatened in natural habitats (IUCN 2000), indicating that the biodiversity loss has been significant in the natural forests of Bangladesh. Biodiversity loss in Bangladesh is mainly attributed to increasing population pressure, anthropogenic disturbances inside and around the forest, over-extraction of forest resources, absence of ecosystem-based forest management practices, and lack of proper conservation initiatives (Dutta et al. 2015). Therefore, the declaration of forest land into Protected Area (PA) is considered as a fundamental strategy to combat deforestation and forest degradation to conserve biodiversity in terrestrial ecosystems. Over the years, forest areas of the country have been declared as PA to meet the conservation priorities of Bangladesh which are divided into different categories including national parks, biodiversity conservation areas, eco-parks, and wildlife sanctuaries (Khan et al. 1997; Hassan 2000; Mukul et al. 2008).

Medha Kachhapia National Park (MKNP) is one of the $\mathrm{PA}$ of Bangladesh belonging to the category of IV according to the IUCN PA management categories (IUCN 1994). The forests in this area are among the few remaining but degraded natural forest patches of Bangladesh. These forest patches have been famous for harboring century-old mother Garjan trees (Dipterocarpus spp.) (Biswas and Misbahuzzaman 2008) and serving as an active corridor of Asian elephants (Elephas maximus). The presence of elephants in this national park indicates that the forest might have the ability to support rich biological diversity and possesses the elements of an ideal forest environment. However, the forest area of MKNP is subjected to degradation because of encroachment inside the forest area for settlement and agricultural expansions.

Acquiring and updating the forest's plant biodiversity is an enormous, but necessary, task to get a deeper insight 
into forest dynamics, plant-animal interactions, and nutrient cycling (Hossain et al. 2013). Thus, assessing the floristic composition is still considered an important tool to make good decisions on forest management actions so that the sustainability and resiliency of a forest ecosystem can be ensured (Nath et al. 2000). Over the years, numerous researches have been conducted to assess the plant species diversity in different PAs of Bangladesh (e.g., Nath et al. 2000; Uddin and Misbahuzzaman 2007; Motaleb and Hossain 2011; Hossain et al. 2013; Hossain and Hossain, 2014). However, there is no research carried out to assess the tree diversity and structural composition of the MKNP forest. Here, the study aimed (i) to assess the quantitative structure of the tree species; and (ii) to quantify tree species diversity and composition of the MKNP of Bangladesh. By fulfilling these objectives, the study attempted to provide a comprehensive list of tree species along with their present status, diversity, and composition at the MKNP. The findings of this study could aid forest managers of MKNP to plan, designing, and implement proper forest conservation initiatives. Besides, a complete list of tree species diversity and quantitative structure of MKNP could assist policymakers to prioritize tree species or zones that need immediate conservation attention which in a broader context assist to fulfill the targets of biodiversity conservation of the country.

\section{MATERIALS AND METHODS}

\section{Study area}

The study was conducted in the Medha Kachhapia National Park (MKNP), a tropical semi-evergreen forest, located in the south-eastern part of Bangladesh (Figure 1). MKNP is situated under the Medha Kachhapia Forest Beat of Fulchari Range under Cox's Bazar North Forest Division of Bangladesh. It comprises an area of 395.92 ha, and lies between $21^{\circ} 37^{\prime} 47^{\prime \prime} \mathrm{N}$ latitude and 92 $04^{\prime} 36^{\prime \prime} \mathrm{E}$ longitude. The forest area has been declared as MKNP under the provision of Wildlife Preservation Order 1973 in the year 2004 (BFD 2015).

The geology of MKNP is largely made up of gently sloping hills. The soil in the area ranges from clay to clayey loam on the flat ground whereas sandy loam to coarse sand on hilly land. The climate is characterized by a humid, tropical climate with little temperature variability. Temperatures remain high with some seasonal variability, and mean monthly temperature ranges from $11.11^{\circ} \mathrm{C}$ in January to $35^{\circ} \mathrm{C}$ in May. Rainfall is high during the monsoon season, with pre-monsoon rains beginning in April-May, and post-monsoon rains lasting until October. November to March-April is usually a relatively dry period. There is heavy dew during winter when rainfall is low.

During the field data collection, it was observed that the forested area of MKNP was subjected to forest degradation as a result of different types of anthropogenic pressures such as agricultural expansion, road construction, encroachment, illegal felling activities, etc. (Figure 2).

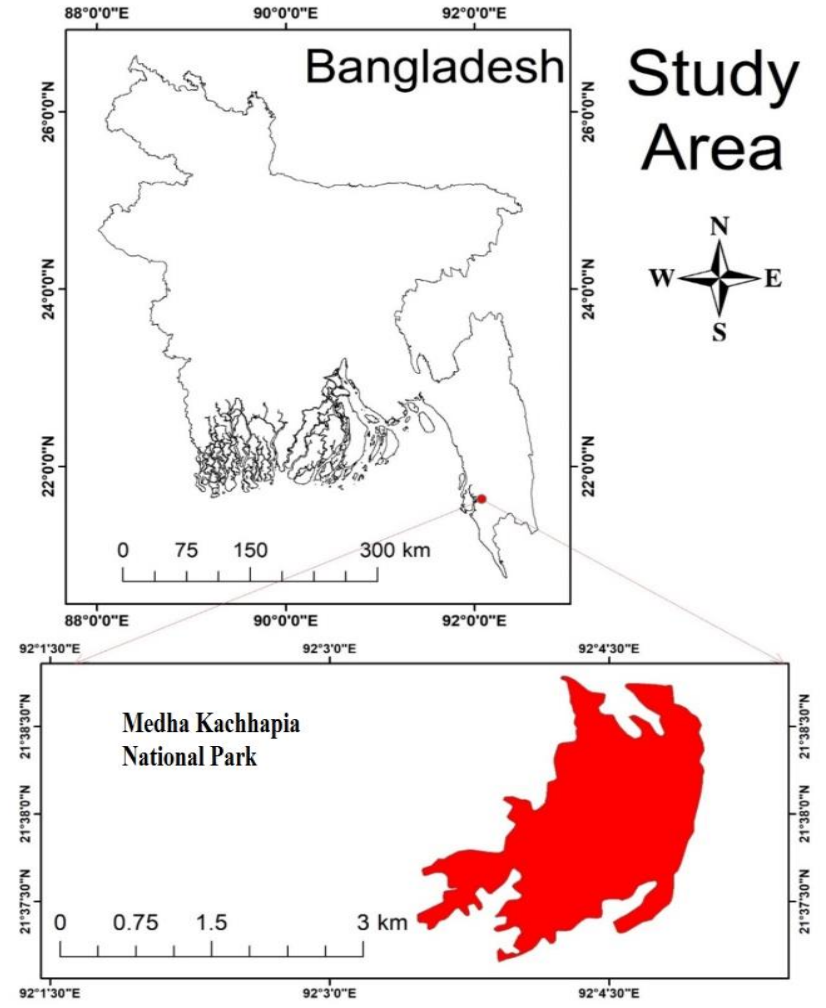

Figure 1. Map of Medha Kachhapia National Park, Bangladesh

\section{Sampling framework}

The study followed the systematic sampling approach to determine the sample plots and to assess the tree species diversity of MKNP. There were 28 plots, each of $50 \mathrm{~m}$ x 50 $\mathrm{m}$ square-quadrant size, taken at $400 \mathrm{~m}$ intervals. Plants having $\geq 10 \mathrm{~cm}$ Diameter at Breast Height $(\mathrm{DBH})$ were considered as trees. Hence, only trees having $\geq 10 \mathrm{~cm} \mathrm{DBH}$ were considered for measurement. From each plot, the number of each tree was counted and recorded in the field data sheet while total height and DBH of the trees were measured using Suunto Clinometer and diameter tape respectively. The standard scientific method of $\mathrm{DBH}$ measurement was followed in other critical situations, i.e., buttressed stem, leaned tree, slope, etc. (Walker et al. 2010). Tree species were identified directly in the field with assistance from the staff of the Bangladesh Forest Department and local guides.

\section{Data analysis}

For each of the tree species, density, relative density, frequency, relative frequency, abundance, relative abundance, and Importance Value Index (IVI) were calculated by using the methods described in Dallmeier et al. (1992), and Shukla and Chandel (2000). Species richness was measured by using Margalf's diversity index (Margalef 1958) and species evenness was calculated by Pielou's measure of evenness (Pielou 1966). The species diversity was assessed with Simpson's concentration index and Shannon's information index (Simpson 1949; Shannon and Wiener 1963). The equations used for these purposes are listed below: 


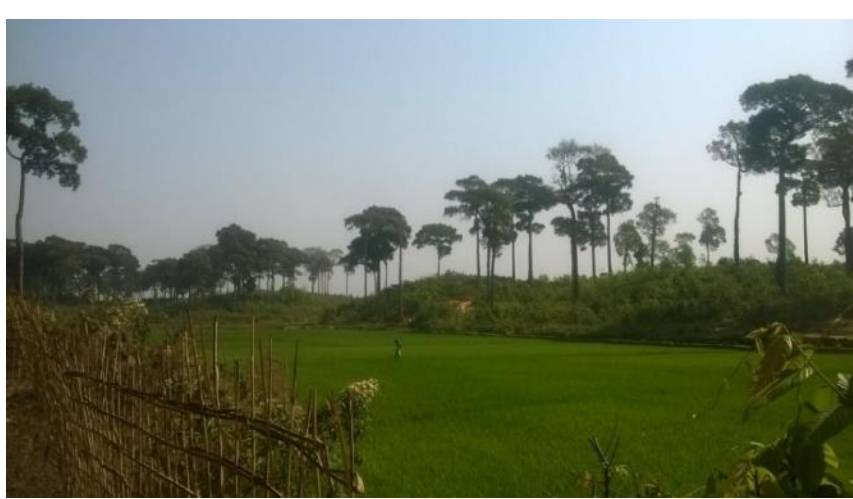

A

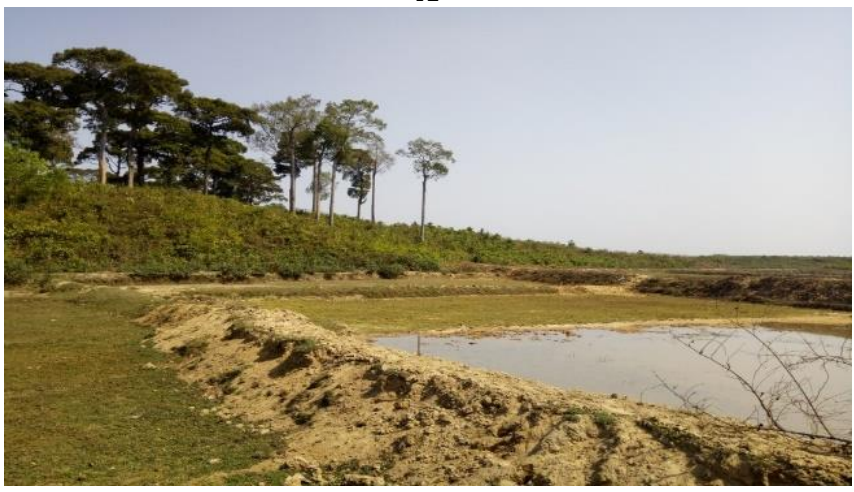

C

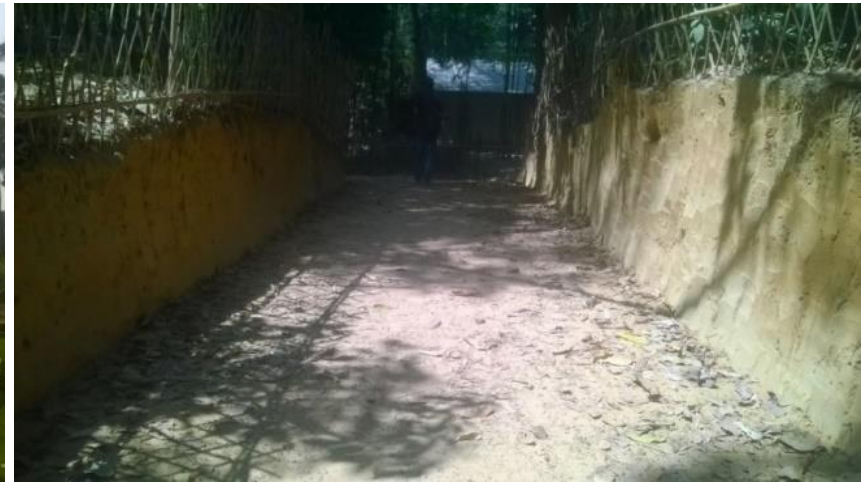

B

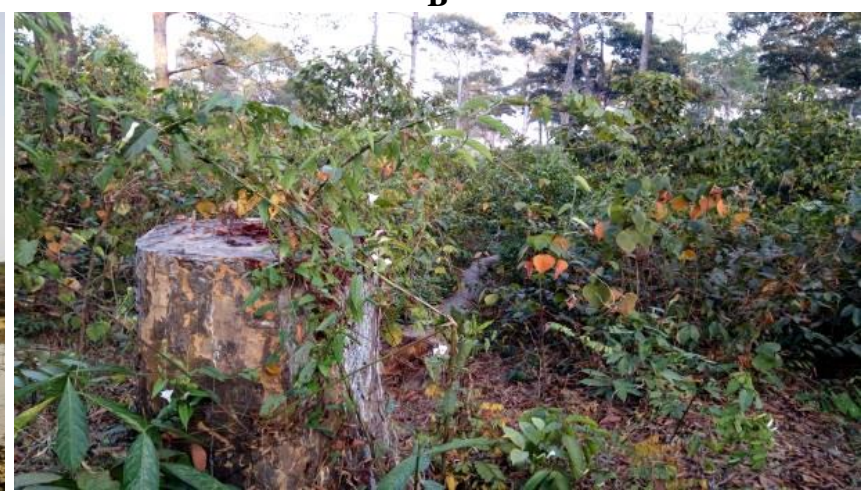

D

Figure 2. Anthropogenic disturbances inside Medha Kachhapia National Park, Bangladesh. A. Agricultural expansion in MKNP, B. Human trespass inside MKNP, C. Encroachment inside MKNP, D. Illegal felling at MKNP

(i) Density of a a species = $\frac{\text { Total number of individuls of a species in all the quadrats }}{\text { Total number of quadrats studied }}$

(ii) Relative density of a species= Total number of individuls of a species in all the quadrats $\times 100$; Total number of individual of all species

(iii) Frequency of a species = $\frac{\text { Total number of quadrats in which the species occur }}{\text { Total number of quadrats stwdied }} \times 100$;

(iv) Relative Frequency of a species = $\frac{\text { Frequency of one species }}{\text { Sum of all frequencies }} \times 100$;

(v) Abundance of a species = Total number of individuls of a species in all the quadrats.

Total number of quadrats in which the species occurs ;

(vi) Relative abundance of a species = $\frac{\text { abundance of one species }}{\text { Total abundance of all the species }} \times 100$;

(vii) Relative dominance of a species $=$ $\frac{\text { Total basal area of a species in all the quadrats }}{\text { Total basal area of all species in all quadrats }} \times 100$

(viii) Importance Value Index (IVI) = Relative density (RD) + Relative frequency (RF) + Relative Abundance (RA) (Shukla and Chandel 2000; Dallmeier et al. 1992) (ix) Shannon-Wiener index: $\mathrm{H}=-\sum_{i=1}^{n} P_{i} \ln P_{i}$

where, quantity $\mathrm{Pi}$ is the proportion of individuals found in the $i^{\text {th }}$ species and is estimated using the maximum likelihood estimator and $\mathrm{Pi}=\frac{n i}{N}$ where, ni is the number of individuals in the $i^{\text {th }}$ species, and $\mathrm{N}$ is the total number of individuals of all species. Information is maximum when the probabilities (number of individual) for all species are equal and information is zero if there is only one possibility.

(x) Simpson's Index: $\mathrm{D}=\sum P i^{2}$

where, $\mathrm{Pi}=\mathrm{ni} / \mathrm{N}$, ni is the number of individuals of each species; $\mathrm{N}$ is the total number of trees of all species.

(xi) Margalef's Index of Species Richness $\mathrm{R}=(\mathrm{S}-1) / \mathrm{ln} \mathrm{N}$

where, $\mathrm{R}=$ Species richness index, $\mathrm{S}=$ Total no. of species, and $\mathrm{N}=$ Total no. of individuals of all species.

(xii) Pielou's Measure of Evenness: $E=H / \ln S$

where, $\mathrm{E}=$ Species evenness, $\mathrm{H}=$ the Shannon-Weiner Index of Diversity, and $\mathrm{S}=$ Total No. of species.

(xiii) Basal area $=\pi \mathrm{D}^{2} / 4$; where, $\mathrm{D}=$ Diameter at breast height, and $\pi=3.1416$. 


\section{RESULTS AND DISCUSSION}

\section{Tree species composition in MKNP}

This study measured a total of 250 tree stems (34.48 stems/ha) belonging to 10 tree species at 28 sampled plots of MKNP (Table 1). These 10 tree species belong to 6 families and 7 genera (Tables 1,2). Among the recorded families, Dipterocarpecae had the highest number of species (3) followed by Mimosaceae (2), Anacardiaceae (1), Clusiaceae (1), Moraceae (1) and Myrtaceae (1).

On the other hand, the study showed the ShannonWienner Diversity index and Simpson's index of 1.16 and 0.45504 respectively. The study also found that Margalef's index of species richness and Pielou's measure of species evenness were 1.63 and 0.2106 respectively (Table 2 ). The average stem density of MKNP was found at 34.48 stems/ha (Table 2) while the total basal area was 11.97 $\mathrm{m}^{2} /$ ha (Figure 4)

\section{Structural composition of different tree species in MKNP \\ Tree species in different height class}

The study had determined six height classes to assess the vertical distribution of tree species in MKNP, i.e. $\leq 5$ $\mathrm{m}, 5.1-\leq 15 \mathrm{~m}, 15.1-\leq 25 \mathrm{~m}, 25.1-\leq 35 \mathrm{~m}, 35.1-\leq 45 \mathrm{~m}$ and 45.1- $\leq 55 \mathrm{~m}$. Most of the height classes (i.e. $\leq 5 \mathrm{~m}, 15.1-\leq 25$ $\mathrm{m}, 25.1-\leq 35 \mathrm{~m}, 35.1-\leq 45 \mathrm{~m}$ and $45.1-\leq 55 \mathrm{~m}$ ) were dominated by Dipterocarpus costatus whereas Acacia auriculiformis dominated only in $5.1-\leq 15 \mathrm{~m}$ height class $(16.00 \%)$ (Table 3$)$. The highest percentage $(44.40 \%)$ of tree stems was recorded in $25.1-\leq 35 \mathrm{~m}$ height class (111 tree individuals and 3 species) followed by $25.6 \%$ tree stems in $5.1-\leq 15 \mathrm{~m}$ height class (64 tree individuals and 3 species), $18.80 \%$ tree stems in $35.1-\leq 45 \mathrm{~m}$ height class (47 tree individuals and 2 species) and $8 \%$ tree stems in $15.1-\leq$ $25 \mathrm{~m}$ height class (20 tree individuals and 7 species). The lowest percentage $(1.60 \%)$ of tree stems were found in $\leq 5$ $\mathrm{m}$ (4 tree individuals and 2 species) and $45.1-\leq 55 \mathrm{~m}$ height class (4 tree individuals and 1 species) (Table 3; Figure 3.B).

In the MKNP, the upper canopy $(45.1 \leq 55 \mathrm{~m})$ was dominated only by $D$. costatus. The second stratum $(35.1 \leq$ $45 \mathrm{~m}$ ) was dominated by $D$. costatus and $D$. turbinatus while the third stratum $(25.1-\leq 35 \mathrm{~m})$ was dominated by $D$. costatus, and $D$. turbinatus. The fourth stratum (15.1- $\leq 25$ $\mathrm{m})$ was dominated by $D$. costatus, $M$. indica, $D$. turbinatus, Acacia mangium, Artocarpus heterophyllus, and Syzygium cumini, whereas the fifth stratum $(5.1-\leq 15 \mathrm{~m})$ was dominated by $A$. auriculiformis, D. costatus, D. turbinatus, $M$. indica, A. heterophyllus, A. mangium, and Hopea odorata. The lowest tree stratum $(\leq 5 \mathrm{~m})$ was dominated by the young poles of Acacia auriculiformis and D. costatus (Table 3).

Table 1. Tree species $(\geq 10 \mathrm{~cm}$ dbh) recorded in Medha Kachhapia National Park, Bangladesh

\begin{tabular}{lll}
\hline Local name & Scientific name & Family \\
\hline Akashmoni & Acacia auriculiformis & Mimosaceae \\
Mangium & Acacia mangium & Mimosaceae \\
Kanthal & Artocarpus heterophyllus & Moraceae \\
Dhulia garjan & Dipterocarpus altatus & Dipterocarpaceae \\
Baitta Garjan & Dipterocarpus costatus & Dipterocarpaceae \\
Telly Garjan & Dipterocarpus turbinatus & Dipterocarpaceae \\
Telsur & Hopea odorata & Dipterocarpaceae \\
Kao & Garcinia cowa & Clusiaceae \\
Aam & Mangifera indica & Anacardiaceae \\
Jam & Syzygium cumini & Myrtaceae \\
\hline
\end{tabular}

Table 2. Diversity indices and associated details of tree species recorded in Medha Kachhapia National Park, Bangladesh

\begin{tabular}{ll}
\hline Parameters & Values \\
\hline No. of tree species & 10 \\
No. of families & 6 \\
Stem density (stem/ha) & 34.48 \\
Shannon-Wienner diversity index & 1.16 \\
Simpson's index & 0.45504 \\
Margalef's index of species richness & 1.630003 \\
Pielou's measure of species evenness & 0.21066 \\
\hline
\end{tabular}

Table 3. Percentage distribution (\%) of tree species at different height classes (m) in Medha Kachhapia National Park, Bangladesh

\begin{tabular}{|c|c|c|c|c|c|c|c|}
\hline \multirow{2}{*}{ Scientific name } & \multicolumn{6}{|c|}{ Height classes (m) } & \multirow[b]{2}{*}{ Total } \\
\hline & $\leq 5$ & $5.1-\leq 15$ & $15.1-\leq 25$ & $25.1-\leq 35$ & $35.1-\leq 45$ & 45.1- $\leq 55$ & \\
\hline Acacia auriculiformis & 0.4 & 16 & 0 & 0 & 0 & 0 & 16.4 \\
\hline Acacia mangium & 0 & 1.2 & 0.4 & 0 & 0 & 0 & 1.60 \\
\hline Artocarpus heterophyllus & 0 & 1.6 & 0.4 & 0 & 0 & 0 & 2.0 \\
\hline Dipterocarpus altatus & 0 & 0 & 0 & 0.8 & 0 & 0 & 0.80 \\
\hline Dipterocarpus costatus & 1.2 & 2.4 & 4.4 & 37.6 & 16.8 & 1.6 & 64.00 \\
\hline Dipterocarpus turbinatus & 0 & 2 & 0.8 & 6 & 2 & 0 & 10.80 \\
\hline Garcinia cowa & 0 & 0 & 0.4 & 0 & 0 & 0 & 0.40 \\
\hline Mangifera indica & 0 & 2 & 1.2 & 0 & 0 & 0 & 3.20 \\
\hline Syzygium cumini & 0 & 0 & 0.4 & 0 & 0 & 0 & 0.40 \\
\hline Total & 1.6 & 25.6 & 8 & 44.4 & 18.8 & 1.6 & 100 \\
\hline
\end{tabular}



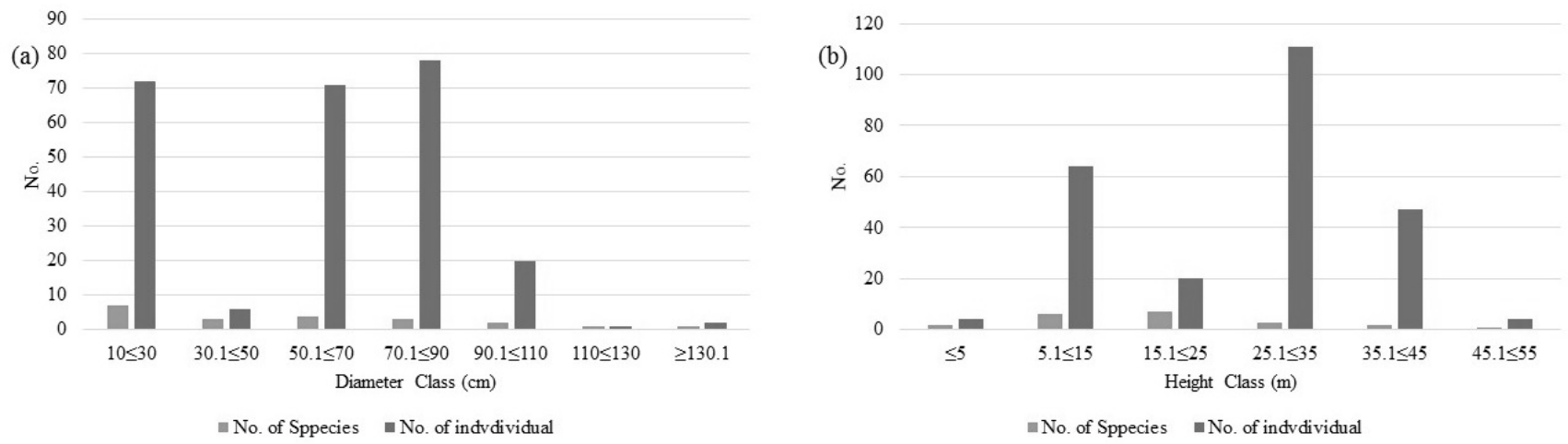

Figure 3. Distribution of the number of species and number of individuals in Medha Kachhapia National Park, Bangladesh based on: A. Diameter class $(\mathrm{cm})$ and B. height classes $(\mathrm{m})$

Table 4. Percentage distribution (\%) of tree species at different diameter classes (cm) in Medha Kachhapia National Park, Bangladesh

\begin{tabular}{|c|c|c|c|c|c|c|c|c|}
\hline Scientific name & $10-\leq 30$ & $30-\leq 50$ & $50-\leq 70$ & $70-\leq 90$ & $90-\leq 110$ & $110-\leq 130$ & $\geq 130.1$ & Total \\
\hline Acacia auriculiformis & 16.4 & 0.00 & 0.00 & 0.00 & 0.00 & 0.00 & 0.00 & 16.4 \\
\hline Acacia mangium & 1.20 & 0.40 & 0.00 & 0.00 & 0.00 & 0.00 & 0.00 & 1.60 \\
\hline Artocarpus heterophyllus & 2.00 & 0.00 & 0.00 & 0.00 & 0.00 & 0.00 & 0.00 & 2.00 \\
\hline Dipterocarpus altatus & 0.00 & 0.00 & 0.00 & 0.80 & 0.00 & 0.00 & 0.00 & 0.80 \\
\hline Dipterocarpus costatus & 2.80 & 1.60 & 24.8 & 26.4 & 7.20 & 0.40 & 0.80 & 64.0 \\
\hline Dipterocarpus turbinatus & 2.80 & 0.40 & 2.80 & 4.00 & 0.80 & 0.00 & 0.00 & 10.8 \\
\hline Hopea odorata & 0.40 & 0.00 & 0.00 & 0.00 & 0.00 & 0.00 & 0.00 & 0.40 \\
\hline Garcinia cowa & 0.00 & 0.00 & 0.40 & 0.00 & 0.00 & 0.00 & 0.00 & 0.40 \\
\hline Mangifera indica & 3.20 & 0.00 & 0.00 & 0.00 & 0.00 & 0.00 & 0.00 & 3.20 \\
\hline Syzygium cumini & 0.00 & 0.00 & 0.40 & 0.00 & 0.00 & 0.00 & 0.00 & 0.40 \\
\hline Total & 28.8 & 2.40 & 28.4 & 31.2 & 8.00 & 0.40 & 0.80 & 100 \\
\hline
\end{tabular}

Tree species in different diameter classes

The study had divided the diameter classes (in $\mathrm{cm}$ ) into seven groups, e.g. $10-\leq 30 \mathrm{~cm}, 30-\leq 50,50-\leq 70,70-\leq 90,90-$ $\leq 110,110-\leq 130$ and $\geq 130.1 \mathrm{~cm}$. Here, most of the diameter classes (i.e. $30-\leq 50,50-\leq 70,70-\leq 90,90-\leq 110,110-\leq 130$ and $\geq 130.1 \mathrm{~cm}$ ) was dominated by $D$. costatus whereas $A$. auriculiformis dominated only in $10-\leq 30 \mathrm{~cm}$ height class $(16.40 \%)$ (Table 4). Besides, the highest percentage $(31.20 \%)$ of tree stems were recorded from $70-\leq 90$ (78 individuals of 3 species) diameter class followed by $21.80 \%$ tree stems from $10-\leq 30 \mathrm{~cm}$ diameter class $(72$ individuals and 7 species), $28.40 \%$ tree stems from $50-\leq 70$ diameter class (71 individuals and 4 species), $8 \%$ tree stems in $90-\leq 110 \mathrm{~cm}$ diameter class (20 individuals and 2 species), $2.30 \%$ tree stems were recorded from $30-\leq 50 \mathrm{~cm}$ diameter class (6 individuals and 3 species) and $0.8 \%$ tree stems from $\geq 130.1 \mathrm{~cm}$ diameter class ( 2 individuals and 1 species). The lowest percentage $(0.4 \%)$ of tree stems were recorded from $110-\leq 130 \mathrm{~cm}$ diameter class (1 individual and 1 species) (Figure 3.A, Table 4).

\section{Quantitative structure of the tree species in MKNP Basal area (BA)}

In terms of basal area, D. costatus dominated with $10.02 \mathrm{~m}^{2} /$ ha. Notable BA for $D$. turbinatus $\left(1.29 \mathrm{~m}^{2} / \mathrm{ha}\right)$ and $M$. indica $\left(0.27 \mathrm{~m}^{2} / \mathrm{ha}\right)$ was found but very low BA was recorded for $A$. auriculiformis $\left(0.10 \mathrm{~m}^{2} / \mathrm{ha}\right), A$. heterophyllus $\left(0.08 \mathrm{~m}^{2} / \mathrm{ha}\right), \quad D$. alatus $\left(0.08 \mathrm{~m}^{2} / \mathrm{ha}\right)$, Garcinia cowa $\left(0.05 \mathrm{~m}^{2} / \mathrm{ha}\right), S$. cumini $\left(0.04 \mathrm{~m}^{2} / \mathrm{ha}\right)$ and $A$. mangium $\left(0.03 \mathrm{~m}^{2} / \mathrm{ha}\right)$. The lowest BA was recorded for $H$. odorata $\left(0.01 \mathrm{~m}^{2} / \mathrm{ha}\right)$ (Figure 4$)$.

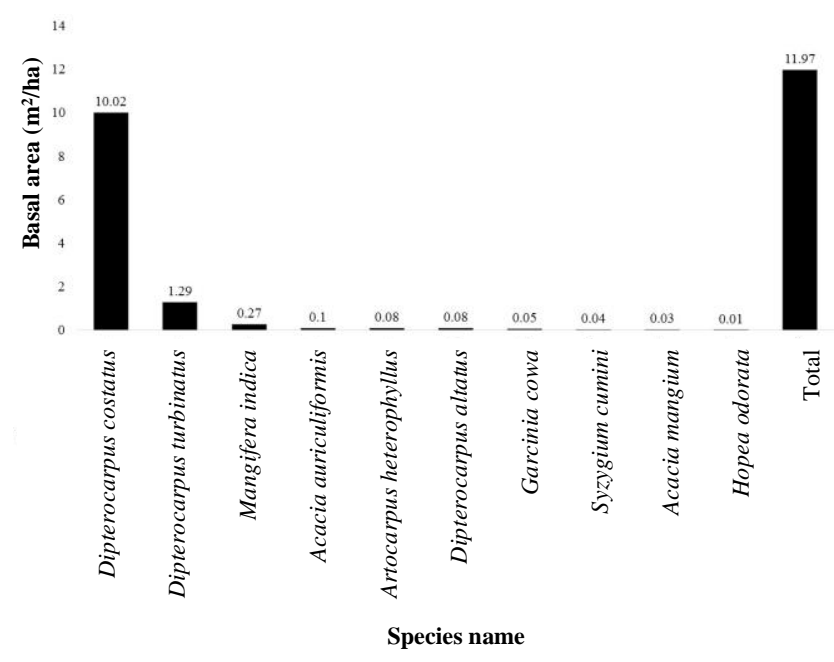

Figure 4. Basal area $\left(\mathrm{m}^{2} / \mathrm{ha}\right)$ of different species in the study area 
Table 5. Relative density, relative frequency, relative abundance and importance value index of different tree species at Medha Kachhapia National Park, Bangladesh

\begin{tabular}{lllll}
\hline Species name & $\begin{array}{l}\text { RD } \\
(\mathbf{\%})\end{array}$ & $\begin{array}{l}\text { RF } \\
(\mathbf{\%})\end{array}$ & $\begin{array}{l}\text { RA } \\
(\mathbf{\%})\end{array}$ & IVI \\
\hline Acacia auriculiformis & 16.4 & 6.12 & 33.3 & 55.82 \\
Acacia mangium & 1.6 & 4.1 & 4.87 & 10.57 \\
Artocarpus heterophyllus & 2 & 2.04 & 12.18 & 16.22 \\
Dipterocarpus altatus & 0.4 & 2.04 & 2.44 & 4.88 \\
Dipterocarpus costatus & 64.4 & 55.1 & 14.44 & 133.94 \\
Dipterocarpus turbinatus & 10.8 & 22.45 & 5.98 & 39.23 \\
Hopea odorata & 0.4 & 2.03 & 2.42 & 4.85 \\
Garcinia cowa & 0.4 & 2.04 & 2.44 & 4.88 \\
Mangifera indica & 3.2 & 2.04 & 19.49 & 24.73 \\
Syzygium cumini & 0.4 & 2.04 & 2.44 & 4.88 \\
Total & 100 & 100 & 100 & 300 \\
\hline
\end{tabular}

Note: Relative density (RD), relative frequency (RF), relative abundance (RA) and importance value index (IVI)

\section{Relative Density (RD), Relative Frequency $(R F)$, Relative} Abundance (RA) and Importance Value Index (IVI)

In the case of RD, it was found that most of the MKNP area was occupied by $D$. costatus. The highest RD was recorded for D. costatus $(64.4 \%)$ while the lowest RD was found for D. altatus, G. cowa, S. cumini and H. odorata ( $0.4 \%$ each). Besides, the tree species with the highest RF was found for D. costatus $(55.10 \%)$, whereas the lowest RF was $2.04 \%$ which found for D. altatus, A. heterophyllus, $G$. cowa, H. odorata, M. indica, and S. cumini. Furthermore, the highest RA was recorded for $A$. auriculiformis $(33.30 \%)$ and the lowest RF was found for D. altatus $(2.44 \%)$, G. cowa, H. odorata $(2.44 \%)$, and S. cumini $(2.44 \%)$. Finally, the highest IVI was found for $D$. costatus (133.94\%), while the lowest IVI was recorded for $H$. odorata $(2.45 \%)$. Another notable IVI was found in $A$. auriculiformis $(55.82 \%)$ and D. turbinatus (39.23) (Table $5)$.

\section{Discussion}

In the present study, MKNP showed a poor tree composition with only 10 species recorded (Table 1 and 2) and also showed the absence of natural distribution of mature tree species except for D. costatus (Table 3 and 4; Figure 3.A, 3.B) which might be attributed by the continuous degradation of the forest ecosystem of MKNP. Deforestation and forest degradation were mostly caused by forest encroachment, agricultural expansions, and other anthropogenic disturbances inside the forest areas (Figure 2).

The floristic composition of MKNP was very poor in comparison to other PAs of Bangladesh. For example, 31 tree species were recorded at Dulhazara Safari Park (Uddin and Misbahuzzaman 2007) and 48 tree species at Dudhpukuria-Dhopachori Wildlife Sanctuary of Chittagong (South) Forest Division (Hossain et al. 2013). The stem density of MKNP (34.48 stems/ha) was also lower than the other PAs of Bangladesh. For example, Motaleb and Hossain (2011) found 62 naturally growing tree species having the $\mathrm{DBH} \geq 10 \mathrm{~cm}$ in 1.2 hectares sampled area in Tankawati Natural Forest

Most of the diversity indices also showed a poor representation of floral diversity in the MKNP (Table 2) compared to other PAs of Bangladesh. For example, the Shannon-Wiener diversity index (1.16) was lower in Chunati Wildlife Sanctuary (3.762) (Hossain and Hossain 2014), Sitapahar Reserve Forest (2.98) (Nath et al. 2000), Tankawati Natural Forest of Chittagong (3.25) (Motaleb and Hossain 2011) and Dudhpukuria-Dhupachori Wildlife Sanctuary (4.45) (Hossain et al. 2013). Margalef's index also showed poor diversity of tree species at MKNP with a value of just 1.63. Researchers found higher Margalef's index in different PAs than MKNP; for example, 23.46 in Dudhpukuria-Dhupachori Wildlife Sanctuary (Hossain et al. 2013), 19.21 in Chunati Wildlife Sanctuary (Hossain and Hossain 2014) and 14.83 in Tankawati natural forest of Chittagong (Motaleb and Hossain 2011). Species evenness (0.2106) was also found lower in MKNP than Chunati Wildlife Sanctuary (0.7834) (Hossain and Hossain 2014) and Dudhpukuria-Dhupachori Wildlife Sanctuary (0.853) (Hossain et al. 2013).

However, the Simpson's index (0.45504) was found higher in the study area than Chunati Wildlife Sanctuary (0.056) (Hossain and Hossain 2014) and DudhpukuriaDhupachori Wildlife Sanctuary (0.0192) (Hossain et al. 2013). The higher Spimpson's index in the study area might be attributed due to higher RD, RF, RA, and IVI of D. costatus in the MKNP (Table 5).

The study found that the forest patches of MKNP were dominated by different Dipterocarpus spp. especially by $D$. costatus. The D. costatus was found in all height and diameter classes and also had a very high value of IVI (Table 3, 4, and 5) and BA (Figure 4). It had indicated that (i) D. costatus individuals were distributed across the forest of MKNP because of the efficient dispersal of seeds of this tree species throughout the MKNP, (ii) the tree can sustain regeneration and can be recruited successfully in the study area, and (iii) the tree possesses a suitable natural habitat to maintain the optimum growth and development (Tables 3, 4, and 5; Figures 3 and 4). Unfortunately, the study had also found that $A$. auriculiformis had the second-highest percentage at height $(16.4 \%)$ and DBH $(16.4 \%)$ class as well as had the second-highest value of IVI (55.82) although its distribution was limited only in $\leq 5 \mathrm{~m}$ and 5.1$\leq 15 \mathrm{~m}$ height class, and $10-\leq 30 \mathrm{~cm}$ DHB class, and had a lower value of BA $\left(0.1 \mathrm{~m}^{2} / \mathrm{ha}\right)$ (Table 3, 4 and 5; Figure 4). This finding came with the notion that recent plantation activities were carried out at MKNP with $A$. auriculiformis, and that $A$. auriculiformis became a preferable plantation tree species in the study area in recent years. But, the choice of exotic species for plantation over the native species should be minimized or stopped, if possible; otherwise, the habitat of mother trees of $D$. costatus might be disturbed because of the continuation of $A$. auriculiformis plantation. Thus, plantation activities should be concentrated with the different Dipterocarpus spp. with a special emphasis given on $D$. costatus as this forest patch was dominated by these species. Besides, the habitat of $D$. costatus was under the threat of different anthropogenic 
pressures inside the forest of MKNP (Figure 2). Further continuation of different anthropogenic activities such as deforestation, agricultural practices and forest encroachments (Figure 2) could decline the natural habitat of this globally vulnerable tree species (Ly et al. 2017). Thus, these anthropogenic activities should be stopped immediately to protect the habitat of mother D. costatus trees.

\section{Conclusion and recommendations}

In Bangladesh, saving the remaining natural forests from further degradation and deforestation is a key challenge for policymakers. PA could play a key role to reduce such deforestation, and wildlife habitat degradation while strengthening biodiversity conservation strategies. Unfortunately, the study found that the MKNP was low in tree species diversity and composition in comparison to other PAs of Bangladesh. The study also found that the forest of MKNP possesses a suitable habitat for Dipterocarpus spp. especially for D. costatus. However, A. auriculiformis becomes the major plantation species in recent times in this area which could degrade the habitat of D. costatus tree. Hence, plantations with native tree species especially with $D$. costatus should be prioritized to replace the $A$. auriculiformis. The study also prescribes to control anthropogenic disturbances inside the forest of MKNP to preserve and sustainably manage the natural habitat of $D$. costatus along with other native flora and fauna. Awareness campaigns from Governments and local NGOs could be an effective method to halt the habitat degradation of mother D. costatus trees. Future conservation actions of this vulnerable tree species could be made through $e x$-situ collections (Ly et al. 2017) because globally D. costatus has not been recorded in any ex-situ collection (BGCI 2017).

\section{ACKNOWLEDGEMENTS}

Authors give their heartfelt thanks to the Institute of Forestry and Environmental Sciences of Chittagong University, Bangladesh, and Bangladesh Forest Department for the support during the fieldwork. The authors also would like to thank two anonymous reviewers for their constructive comments and suggestions in an earlier version of the manuscript.

\section{REFERENCES}

Ahmed ZU, Begum ZT, Hassan MA, Khondker M, Kabir SMH, Ahmad M, Ahmed ATA, Rahman AKA, Haque EU. 2008. Encyclopedia of flora and fauna of Bangladesh. Vol. 5-12. Asiat Soc Dhaka, Bangladesh.

BFD. 2015. Management Plan for Medha Kachhapia National Park, Bangladesh Forest Department, Dhaka.

BFD. 2019. Forest Department, Bangladesh. Available at: www.bforest.gov.bd/

BGCI. 2017. PlantSearch. Botanic Gardens Conservation International, London. Available at: www.bvgci.org/plant_search.php
Biswas SR, Misbahuzzaman K. 2008. Tree species diversity and regeneration traits of the dominant species in a dipterocarp forest in Bangladesh: implications for conservation. Int J Biodivers Sci Ecosyst Serv Manag 4 (2): 81-91, DOI: 10.3843/Biodiv.4.2:2

Dallmeier F, Kabel M, Rice R. 1992. Methods for long-term biodiversity inventory plots in protected tropical forests. In: Dallmeier F (ed.). Longterm monitoring of Biological Diversity in Tropical Forest Areas: Methods for Establishment and Inventory of Permanent plots. 11-46, UNESCO, Paris, [France].

Dutta S, Hossain MK, Hossain, MA, Chowdhury P. 2015. Exotic plants and their usage by local communities in the Sitakunda botanical garden and Eco-Park, Chittagong, Bangladesh. For Res 4 (1): 136. DOI: 10.4172/21689776.1000136

FMP. 1993. Forestry Master Plan, Ministry of Environment and Forest, Government of the Republic of Bangladesh.

Hassan MM. 2000. Biodiversity and Conservation. Hasan Book House Dhaka, Bangladesh.

Hossain M, Hossain M, Salam M, Rahman S. 2013. Composition and diversity of tree species in Dudhpukuria-Dhopachori Wildlife Sanctuary of Chittagong (South) forest division. Bangladesh. Res J Pharm Biol Chem Sci 4: 1447-1457. DOI: 10.7747/JFES.2015.31.3.192

Hossain MK, Hossain MA. 2014. Biodiversity of Chunati Wildlife Sanctuary: Flora. Arannayk Foundation, Dhaka, [Bangladesh].

Hossain MK. 2001. Overview of the forest biodiversity in Bangladesh. Assessment, conservation and sustainable use of forest biodiversity (CBD Technical Series no. 3). Secretariat of the Convention on Biological Diversity, Montreal, Canada.

IUCN. 1994. Guidelines for Protected Area Management Categories, The World Conservation Union, Cambridge.

IUCN. 2000. Red List of Threatened Animals of Bangladesh. IUCN-The World Conservation Union. Available at: https://portals.iucn.org/library/sites/library/files/documents/RL-549.3003-v.1.pdf

Khan ML, Menon S, Bawa, KS. 1997. Effectiveness of the protected area network in biodiversity conservation: a case-study of Meghalaya state. Biodivers Conserv 6: 853-868. 10.1023/B:BIOC.0000010406.35667.c0

Liang J, Crowther TW, Picard N, Wiser S, Zhou M, Alberti G, Reich PB. 2016. Positive biodiversity-productivity relationship predominant in global forests. Science 354 (6309): aaf8957-1-12. DOI: 10.1126/science.aaf8957

Ly V, Nanthavong K, Pooma R, Luu HT, Nguyen HN, Barstow M, Vu VD, Hoang VS, Khou E, Newman M. 2017. Dipterocarpus costatus. The IUCN Red List of Threatened Species. 2017:e.T33010A2830217. DOI: 10.2305/IUCN.UK.20173.RLTS.T33010A2830217.en

Margalef R. 1958. Information theory in ecology, Gen Syst 3: 36-71.

Motaleb M, Hossain M. 2011. Assessment of tree species diversity of Tankawati natural forests, Chittagong (South) Forest Division, Bangladesh. Eco-Friendly Agric J 4: 542-545.

Mukul SA, Uddin MB, Uddin MS, Khan M, Marzan B. 2008. Protected areas of Bangladesh: current status and efficacy for biodiversity conservation. Proc Pak Acad Sci 45: 59-68.

Nath TK, Hossain MK, Alam MK. 2000. Assessment of tree species diversity of Sitapahar Forest Reserve, Chittagong Hill Tracts (South) Forest Division, Bangladesh. Indian For 126:16-21.

Pielou EC. 1966. Species-diversity and pattern-diversity in the study of ecological succession. J Theor Biol 10: 370-383. DOI: 10.1016/00225193(66)90133-0

Rahman M, Hossain M. 2002. Distribution pattern of medicinal tree species in Chunati Wildlife sanctuary of Chittagong. J Trop Med Plants 3: 65-72.

Shannon CE, Wiener W. 1963. The Mathematical Theory of Communities. University of Illinois Press, Urbana.

Shukla RS, Chandal PS. 2000. Plant Ecology and Soil Science (9th ed.). Ramnagor S. Chand and Company Limited, New Delhi [India].

Simpson EH. 1949. Measurement of diversity. Nature 163: 688. DOI: 10.1038/163688a0

Sobuj NA, Rahman M. 2011. Assessment of plant diversity in Khadimnagar National Park of Bangladesh. Int J Environ Sci 2: 79-91.

Uddin SMM, Misbahuzzaman K. 2007. Tree species diversity in Dulhazara Safari Park of Bangladesh. Malays Appl Biol 36(2): 33-40.

Walker S, Pearson T, Harris N, Grimland S, Brown S. 2012. Terrestrial carbon measurement standard operating procedures. Winrock International. https://www.winrock.org/wpcontent/uploads/2016/03/Winrock_Terrestrial_Carbon_Field_SOP_M anual_2012_Version.pdf 